\title{
Ammonia Oxidizing Archaea and Bacteria in East Asian Paddy Soils-A Mini Review
}

\author{
Hussnain Mukhtar, Yu-Pin Lin * and Johnathen Anthony \\ Department of Bioenvironmental Systems Engineering, National Taiwan University, No. 1, Sec. 4, Roosevelt \\ Road, Taipei 10617, Taiwan; agricultureenvironment33@gmail.com (H.M.); f03622040@ntu.edu.tw (J.A.) \\ * Correspondence: yplin@ntu.edu.tw; Tel.: +886-2-3366-3467
}

Received: 24 August 2017; Accepted: 15 November 2017; Published: 18 November 2017

\begin{abstract}
Ammonia oxidation is crucial in nitrogen removal and global nitrogen dynamics since it is the first step of the nitrification process. In this review, we focus on the distribution and community structure of ammonia-oxidizing archaea (AOA) and ammonia-oxidizing bacteria (AOB) in East Asian paddy soils with variable soil properties. The available East Asian paddy soil data shows that the ammonium concentration and $\mathrm{pH}$ ranges from 0.4 to $370 \mathrm{mg} / \mathrm{kg}$ and 5.1 to 8.2 , respectively. Our meta-analysis suggest that AOA specific gene sequences are generally more abundant than those of $\mathrm{AOB}$ in both acidic and alkaline paddy soils, where Nitrosophaera and Nitrosospira amoA clusters mainly dominate the microbial community, respectively. In addition, the contribution of ammonia oxidizers to the nitrification process has been demonstrated using DNA-SIP (DNA-based stable-isotope probing); the results of these studies indicate that $\mathrm{pH}$ is the most important factor in niche separation of AOA and $\mathrm{AOB}$ under a variety of edaphic conditions. Finally, we discuss a number of other environmental variables that affect the abundance, distribution, and activity of $\mathrm{AOA}$ and $\mathrm{AOB}$ in East Asian paddy soils.
\end{abstract}

Keywords: ammonia-oxidizing archaea; ammonia-oxidizing bacteria; paddy; nitrification

\section{Introduction}

Asia produces and consumes the majority of global rice output, with rice paddies extending thousands of square kilometers. From a biogeochemical perspective, these paddies could be likened to nitrogen rich wetland systems. Increased oxygenation in rhizospheres and bulk soil, attributable to rice porous tissue, has been found to support nitrification in paddy soils [1-3]. Nitrification is a two-step process. It includes the oxidation of ammonia to nitrite followed by the oxidation of nitrite to nitrate. Ammonia oxidation is the first step of nitrification; it is also the rate-limiting step. Therefore, it plays a major role in nitrogen removal and global nitrogen dynamics. For decades, most researchers have considered ammonia-oxidizing bacteria $(\mathrm{AOB})$ as one of the main players in ammonia oxidation. However, the discovery of ammonia oxidizing archaea (AOA) has challenged this view $[2,4,5]$. Consequently, intense research on the importance of $\mathrm{AOA}$ and $\mathrm{AOB}$ in ammonia oxidization has been underway [6-9]. One popular method for exploring the activity of AOA and AOB involves the extraction of DNA of AOA and $\mathrm{AOB}$ from rice rhizospheres and bulk soil; specific sets of Polymerase chain reaction (PCR) primers are then applied to amplify the amoA DNA fragments for further analysis [2,10-13]. By analyzing the amplification results, the community structure, and the distribution of $\mathrm{AOA}$ and $\mathrm{AOB}$ has been studied in acidic and alkaline paddy soils under different fertilization regimes. These studies demonstrated that AOA may be able to adapt to a wider range of aerobic conditions [2,14]. In addition, AOB abundance has been found to increase after the application of nitrogen fertilizers $[15,16]$. Numerous factors affect nitrification mechanisms and microbial communities associated with $\mathrm{AOA}$ and $\mathrm{AOB}$ in soil, such as habitat type, soil temperature, 
soil $\mathrm{pH}$ and the application of nitrogen fertilizers [17-22]. The effects of a wide range of factors on the nitrification processes in paddy soils have been discussed, such as soil types [23], availability of ammonium $[15,16]$ and $\mathrm{pH}$ levels $[24,25]$. Although the importance of AOA and AOB in paddy soil has been extensively explored, microbial contribution to nitrification and microbial response to environmental factor are poorly understood $[25,26]$. Therefore, this mini-review summarizes some recent findings on the abundance, composition, relative importance, metabolic activity, and environmental factors that affect the distribution of $\mathrm{AOA}$ and $\mathrm{AOB}$ in East Asian paddy soils.

\section{Abundance and Composition of AOA and AOB}

The enzyme ammonia monooxygenase (AMO) oxidizes ammonia and converts it into hydroxylamine. Subunits of AMO (alpha-A) found in archaea and bacteria is encoded by the amoA gene. In recent years, the amoA gene of AOA and $\mathrm{AOB}$ has been collected and analyzed by different independent molecular techniques such as Denaturing Gradient Gel Electrophoresis (DGGE) and PCR [4,27] and used as a molecular marker for the activity and diversity of ammonia oxidizers. In addition, modern culture-independent techniques have improved our understanding of the diversity and distribution of $\mathrm{AOA}$ and $\mathrm{AOB}$ in paddy soils. Table 1 summarizes the edaphic properties and $\mathrm{AOA}$ to $\mathrm{AOB}$ ratios in selected paddy soils. The abundance and composition of AOA and AOB in Chinese paddy soils was first investigated in microcosm experiments by Chen et al. (2008) [2], who showed that the AOA outnumbered the AOB irrespective of rice plant presence. The study also showed that AOA to AOB ratios range from 1.2 to 69.3 in bulk and rhizosphere soils. These results were further supported by a study on different Chinese paddy soils where the AOA to AOB ratio varied from 22.9 to 667 [23].

Table 1. Edaphic properties of selected paddy soils.

\begin{tabular}{|c|c|c|c|c|c|c|}
\hline \multirow[b]{2}{*}{ Paddy Fields Location } & \multirow[b]{2}{*}{$\mathrm{pH}$} & OM & $\mathrm{NH}_{4}{ }^{+}$ & $\mathrm{NO}_{3}{ }^{-}$ & \multirow[b]{2}{*}{$\begin{array}{l}\text { AOA/AOB } \\
\text { Ratio }\end{array}$} & \multirow[b]{2}{*}{ References } \\
\hline & & $\begin{array}{l}\mathrm{mg} / \mathrm{kg} \\
{ }^{*} \mathrm{~g} / \mathrm{kg}\end{array}$ & $\mathrm{mg} / \mathrm{kg}$ & $\mathrm{mg} / \mathrm{kg}$ & & \\
\hline Zhejiang province, China & 6.8 & $9.32 *$ & $49.9^{3}$ & $\longrightarrow$ & $1.2-69.3$ & [2] \\
\hline Flooded paddy soils, China & $7.0-7.7$ & - & $45.1-370.0$ & $0.5-1.0$ & $22.9-667$ & [23] \\
\hline $\begin{array}{l}\text { Taoyuan, Hunan Province, } \\
\text { China }\end{array}$ & $5.3-5.4$ & $29.2-41.6$ & $27.1-85.9$ & $0.6-0.9$ & $417-2383$ & [10] \\
\hline $\begin{array}{l}\text { Changshu Ecological } \\
\text { Experimental Station, China }\end{array}$ & $6.3-6.4$ & $20.8-30.7^{*}$ & $13.7-21.4$ & $1.8-2.7$ & $0.39-12.3$ & [16] \\
\hline Eastern China & $5.2-7.6$ & $9.6-43.1 *$ & $9.6-97.9$ & $0.1-6.2$ & $9-20^{1}$ & [28] \\
\hline Albic soil, northeast China & $4.4-6.4$ & $\longrightarrow$ & $10.3-52.2$ & $0.2-7.1$ & $0.65-10.48$ & [27] \\
\hline $\begin{array}{l}\text { Changshu, Jiangsu province, } \\
\text { China }\end{array}$ & $6.8-8.0$ & $6.0-19.3$ * & $0.5-2.5$ & $0.9-8.9$ & $2.6-121.9$ & [11] \\
\hline Southern China & 8.2 & $30.4 *$ & 17.5 & 6.8 & 37.0 & [29] \\
\hline Southern China & $6.0-6.8$ & $10.2-35.4$ * & $4.6-33.9$ & $1.4-11.3$ & $1.9-10.5$ & [29] \\
\hline Southern China & $5.1-7.3$ & $13-46^{*}$ & $3-15$ & $0.3-5$ & $1.91-1048$ & {$[12,25]$} \\
\hline $\begin{array}{l}\text { Experimental rice field, } \\
\text { Suwon, Korea }\end{array}$ & $5.7-7.4^{2}$ & $19-41^{2}$ & 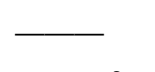 & $\longrightarrow$ & $0.03-0.05^{2}$ & [30] \\
\hline Japanese paddy field & $\longrightarrow$ & $\longrightarrow$ & $10-140^{2}$ & $0-135^{2}$ & $4-346^{2}$ & [7] \\
\hline Jiangsu province, China. & $7.2-8.2$ & & $2.7-10.1$ & $6.4-17.7$ & $1.5-3.5$ & [31] \\
\hline Zhejiang Province, China & $7.0-7.2$ & $\longrightarrow$ & $39.9-143$ & & $1.0-16.9$ & [32] \\
\hline Zhejiang Province, China, & $7.3-8.1$ & $5.8-31.0^{2}$ & $0.42-27$ & $2.1-16$ & $0.97-55.5^{2}$ & [33] \\
\hline Jiangsu Province, China & 6.7 & 20.2 & $276.1^{4}$ & {[} & $1.46-3.8$ & [3] \\
\hline
\end{tabular}

Note: ${ }^{1}$ the ratio of archaeal amoA gene copies to bacterial amoA gene copies per gram dry soil. ${ }^{2}$ approximate data extracted from graphs and tables. ${ }^{3}$ alkali-hydrolysable N. ${ }^{4} \mathrm{~N}$ availability. AOA: ammonia-oxidizing archaea. AOB: ammonia-oxidizing bacteria. OM: organic matter. $\mathrm{NO}_{3}{ }^{-}$: Nitrate. ${ }^{*} \mathrm{~g} / \mathrm{kg}$.

A similar trend was observed in acidic paddy soils, where the $\mathrm{pH}$ ranged from 4.4 to $6.8[27,29]$. These findings are corroborated by the results of Chen et al. (2011) [10], who found that AOA amoA genes outnumbered AOB amoA genes in acidic paddy soils. The results from paddy alkaline soils showed that the AOA to AOB ratio varied between 2.6 and 121.9 [11,29]. Moreover, the study on paddy 
soils from Hussain et al. (2011) [3] showed that the relative ratio of AOA to AOB ranged from 1.46 to 3.8 and rice plant cultivation increased the $\mathrm{AOA}$ and $\mathrm{AOB}$ amo $\mathrm{A}$ gene abundance in the rhizosphere. In general, the proportion of archaeal amoA genes found in East Asian paddy soils is higher than the proportion of bacterial amoA genes, except for two studies on paddy soils, where the AOA to AOB ratios varied from 0.39 to 12.3 [16] and 0.65 to 10.4 [27], respectively. In addition, we found one study where the AOA to AOB ratios varied from approximately 0.03 to 0.05 in Korean paddy soils [30]. In order to understand the community structure and dominant ammonia oxidizer clusters in soil, we conducted a meta-analysis on community structure data of Chinese paddy soils provided by a number of recent studies. A comprehensive picture of $\mathrm{AOA}$ and $\mathrm{AOB}$ community composition is shown in Figures 1 and 2.

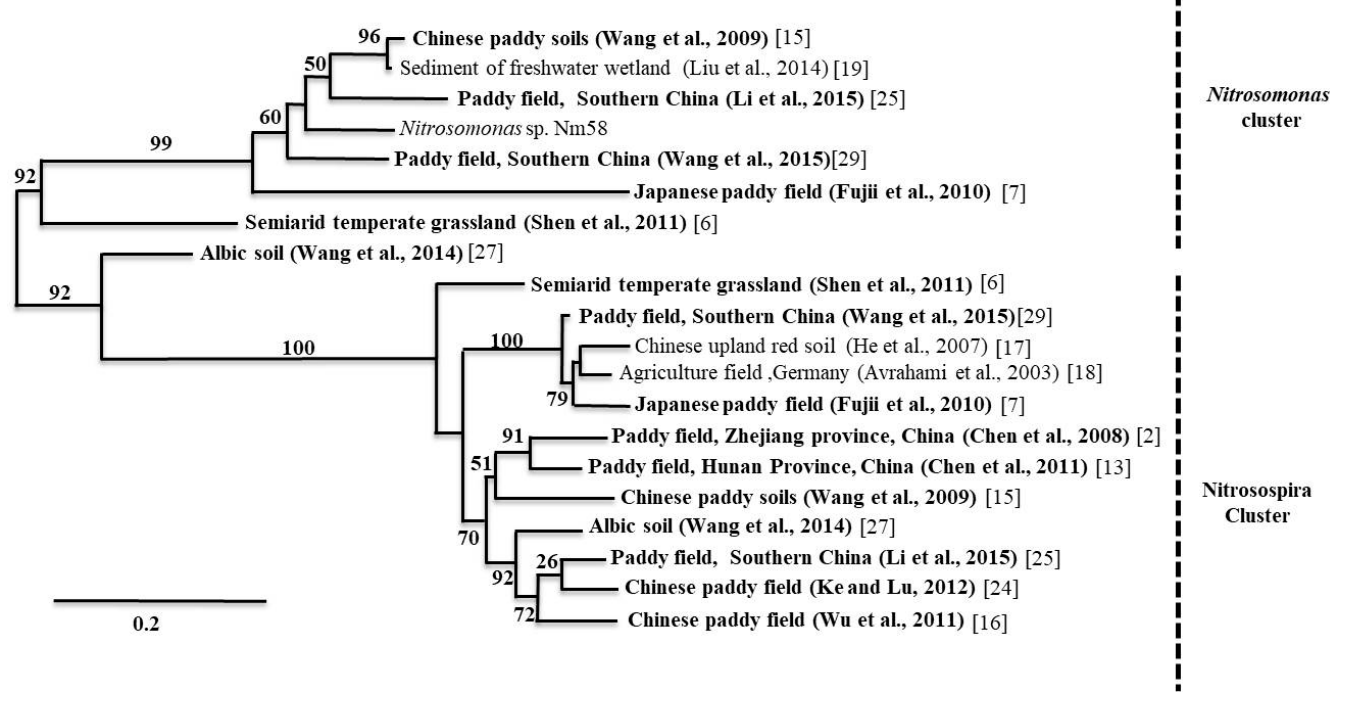

Figure 1. Neighbor-joining phylogenetic trees of AOB (ammonia-oxidizing bacteria) based on amoA gene sequences found in different paddy soil types, where the end nodes of the tree represent soil types. Please see the provided references for more details. In addition, please note that we performed bootstrapping to yield 1000 replicates at each node.

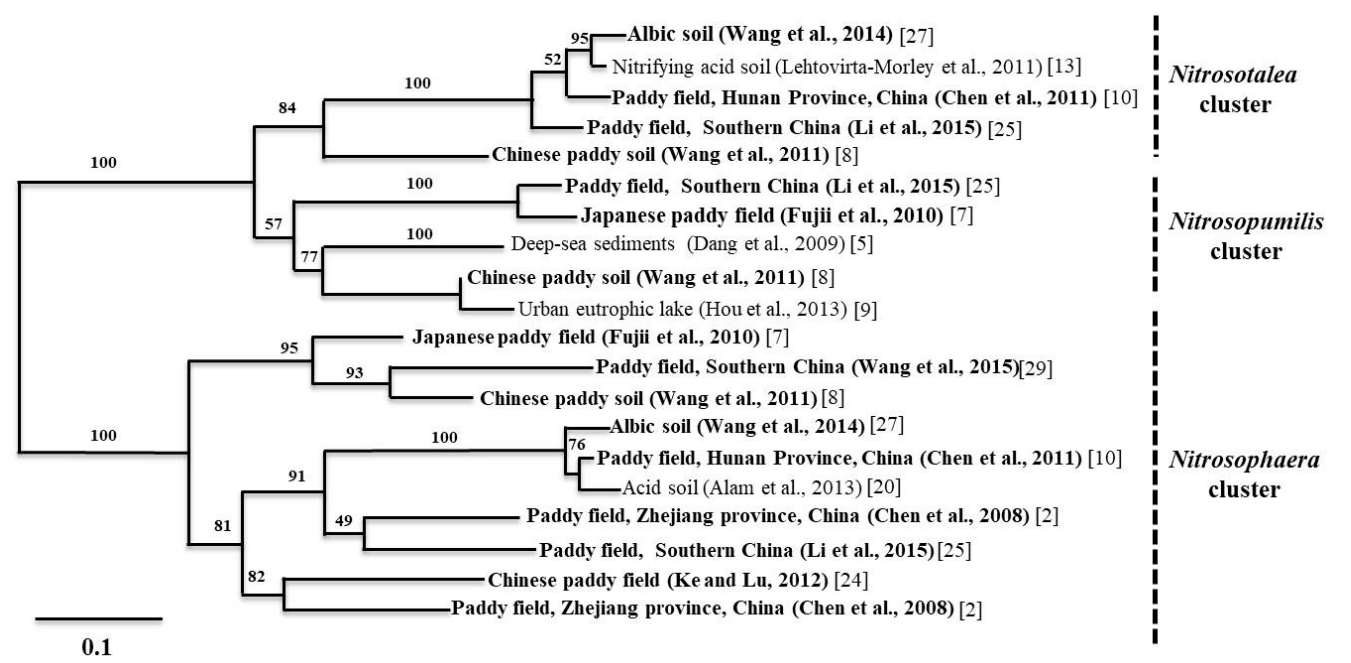

Figure 2. Neighbor-joining phylogenetic trees of AOA (ammonia-oxidizing archaea) based on amoA gene sequences found in different paddy soil types. The end nodes of the tree represent soil types. Please see the provided references for more details. In addition, please note that we performed bootstrapping to yield 1000 replicates at each node. 
The Nitrosophaera amoA cluster dominated the AOA community. As for the AOB community, Nitrosospira and Nitrosomonas were dominant in alkaline and neutral soils. On the other hand, Nitrosospira was the only dominant group in acidic soils. In section three, we provide a more detailed discussion about the environmental driving factors for the distribution and composition of $\mathrm{AOA}$ and $\mathrm{AOB}$ in paddy soils.

\section{AOA and AOB Contribution to Nitrification}

As revealed in Section 2 different phylogenetically distinct groups of ammonia oxidizing archaea and bacteria correspond with different edaphic conditions. Therefore, a deeper understanding of the abundance and community structure of ammonia oxidizers under a wide range of edaphic conditions could help to elucidate the important role that disparate clades play in the full spectrum of edaphic conditions prevalent in rice paddies. For example, Wu et al. (2011) [16] showed that long-term (22 year) nitrogen fertilizer application altered the community structure of AOB rather than AOA in acidic paddy fields, indicating that $\mathrm{AOB}$ dominated ammonia oxidization in the nitrogen rich agricultural study area. The study on long-term nitrogen fertilized agricultural and grassland soils showed that while AOA is more active than AOB in acidic soils, the opposite was true in alkaline soils [26]. Moreover, the DNA-based stable-isotope probing (DNA-SIP) technique has been used to investigate the activity of soil-nitrifying communities. This technique employs a pairwise comparison of ${ }^{13} \mathrm{CO}_{2}$ (labeled microcosms) and ${ }^{12} \mathrm{CO}_{2}$ (control treatment) to assess whether the ${ }^{13} \mathrm{CO}_{2}$ is assimilated by ammonia oxidizers for autotrophic growth. The result of the DNA-based stable-isotope probing technique on paddy fields across southern China showed that AOA was more active in alkaline soils whereas AOB was more active in neutral soils [29]. However, the data on paddy soils from southwestern China [34] demonstrated that nitrification was mainly attributed to AOA in acidic soils, whereas $\mathrm{AOB}$ was mainly responsible for nitrification in alkaline soils. The study also showed that the net nitrification rate for acidic paddy soils ( $\mathrm{pH}$ 5.6) was five times less than alkaline paddy soils ( $\mathrm{pH}$ 8.2), indicating that the acidic archaea dominant paddies have lower nitrification rates. In addition, Liu et al. (2015) [31] showed that the increase in temperature and $\mathrm{CO}_{2}$ concentration positively influenced the nitrification activity in paddy soils. Given the small number of studies investigating the contribution of AOA and AOB to nitrification in paddy soils, further research is clearly needed to understand the role they play in different paddy soils.

\section{AOA and AOB Response to Environmental Factors}

Soil properties affect the behavior and response of $\mathrm{AOA}$ and $\mathrm{AOB}$ communities in paddy soils. In this section, we summarize the soil properties and environmental factors that affect the abundance, distribution, and activity of $\mathrm{AOA}$ and $\mathrm{AOB}$ in East Asian paddy soils.

\subsection{Nitrogen Fertilizer and $\mathrm{pH}$}

Urea is the most commonly used $\mathrm{N}$ fertilizer on East Asian paddies. Figure 3 shows the relationship between paddy soil $\mathrm{pH}$ levels, $\mathrm{AOA} / \mathrm{AOB}$ ratios, and ammonium concentrations as identified by the 14 studies considered in this meta-analysis. Due to the large range of values, we use the logarithmic scale to represent the data. In general, $\mathrm{NH}_{4}$ concentrations and $\mathrm{pH}$ levels in East Asian paddy soils vary from close 0.4 to $370 \mathrm{mg} / \mathrm{kg}$ and 5.1 to 8.2 , respectively. However, the AOA to AOB ratios in paddy soils varies from approximately 1.0 to $2.259 \times 10^{3}$. As for the effects of environmental factors on $\mathrm{AOA}$ and $\mathrm{AOB}$ activity in paddy soils, it is difficult to ascertain a clear relationship between these three variables applicable to the findings of all 14 studies covered here. Despite this, we will attempt to differentiate between three groupings that correspond to the lower left and right quadrant as well as the top half of Figure 3, respectively. The first, lower left quadrant, is a grouping of studies that can be characterized as having alkaline and neutral soils with low ammonium concentrations. As can be seen from Figure 3, two thirds of the studies [11,29-31] observed in this low ammonium concentration (below approximately $25 \mathrm{mg} / \mathrm{kg}$ ) and low AOA/AOB ratios (below 100) had alkaline paddy soils. 
When viewing the points within the confines of this quadrant, we can characterize the activity ratio of AOA/AOB as higher in more neutral/nutrient abundant studies. The second group is composed of studies that have ammonium concentrations greater than $25 \mathrm{mg} / \mathrm{kg}$ and AOA/AOB ratios lower than 60. As can be seen from the figure, all of the studies in this grouping have neutral to acidic soils. In general, at neutral $\mathrm{pH}$ the $\mathrm{AOA} / \mathrm{AOB}$ ratio decreases with increasing nutrient availability. Finally, the third grouping includes the results of three studies with extremely high AOA/AOB ratios, above 300 . As can be seen, two of these studies have acidic soils $[10,25]$, whereas the other has a relatively alkaline soil with high levels of ammonium [23].

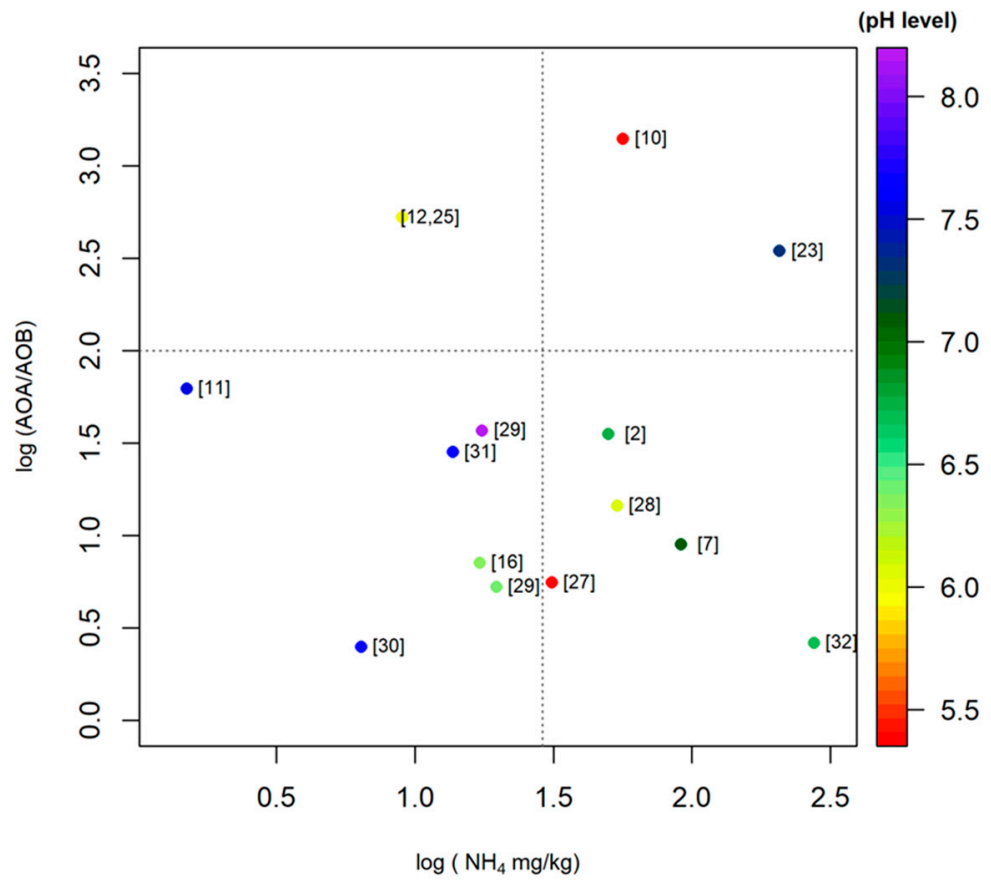

Figure 3. Scatter plot of mean AOA/AOB ratio in different paddy soils (Table 1). The color gradient represents the mean $\mathrm{pH}$ level (acidic to alkaline) in selected paddy soils. The numbers of each point correspond to the data sources, i.e., the references. The Logarithmic scale was used because of the large range of values.

While the data analyzed in this study do not exhibit a general relationship between AOA/AOB ratios, nitrogen fertilizers, and $\mathrm{pH}$ levels, our results may reveal intrinsic biological differences and limitations of archaea and bacteria. The majority of studies on nitrifying communities to date seem to indicate that most fluctuations in AOA to $\mathrm{AOB}$ ratios are attributable to the relative sensitivity of AOB activity to varying edaphic conditions. Conversely, AOA activity appears to be more resistant to fluctuations in edaphic conditions. For example, the data from northern China ( $\mathrm{pH}$ 6.9) show that the application of nitrogen fertilizer affects the community structure of AOB, whereas the AOA community structure remains unchanged [15]. A similar trend was observed in paddy soils ( $\mathrm{pH}$ 6.4) [16] from Jiangsu Province of China, where long term application of nitrogen fertilizer has altered the community structure of $\mathrm{AOB}$ but not AOA. In addition, application of manure fertilizer increased the activity of AOB in paddy soils while the activity of AOA remained constant [35]. Moreover, the data on microcosm studies [24] confirm that the AOA community is less responsive to soil conditions. Hussain et al. (2011) [3] also demonstrated that community structure and abundance of bacterial amoA responded differently to soil conditions (pH 6.7). Interestingly, Chen et al. (2008) [2] reported that rice cultivation stimulated an increase of AOA growth, but not AOB growth in paddies of neutral soil $\mathrm{pH}(6.8)$, suggesting that rice cultivation leads to a greater fluctuation in edaphic conditions, which is favorable for archaea. Chen et al. (2011) [10] also demonstrated that AOA activity 
was relatively higher in paddy soils at lower $\mathrm{pH}$. In contrast, a study on paddy soils of varying $\mathrm{pH}$ (7.3-8.1) that have been under rice cultivation for 50, 100, 300, 2000 years showed that there was no significant difference for archaeal amoA gene abundance whereas bacterial amoA gene abundance varied significantly [33]. These results also showed that the application of $\mathrm{N}$ fertilizer could increase the AOB abundance in paddy soils. On the other hand, archaea also benefit from favorable edaphic conditions. As Jing Wang et al. (2014) [27] observed, the increase in pH from 4.4 to 6.4 resulted in an increase of archaeal amoA gene abundance in paddy soil. These results were further supported by a study on paddy soils from southern China, showing that AOA abundance significantly increased with increasing $\mathrm{pH}$ in acidic and neutral paddy soils [25]. Taken together, however, these results seem to suggest that while both groups benefit from moderate conditions, relatively favorable edaphic conditions, i.e., neutral $\mathrm{pH}$ and an abundance of nutrients, seem to benefit bacteria disproportionately. Unfortunately, it is still not possible to draw general conclusions about which variables, i.e., $\mathrm{pH}$, ammonium availability or other environmental variables, play the most important part in determining the abundance and community structure of AOA and AOB in paddy soils.

As is expected, ammonia oxidization and the activity of ammonia oxidizers tend to be positively correlated with ammonium concentrations. These concentrations, however, vary along the vertical soil profile. Therefore, differences between ammonium concentrations at different soil horizons may indicate that there is a relative increase in archaea activity when limited nutrients are available. One study on the activity and community structure of AOA and AOB at different depths of paddy soils showed that community structure of the AOA and AOB are sensitive to soil depth where $\mathrm{NH}_{4}{ }^{+}$ concentrations varied from 39.9 to 143 ( $\mathrm{pH} 7.0-7.2$ ) [32]. Another study on paddy soil profile analysis conducted by Wang et al. (2014) showed that the AOA community might be better able to adapt to low nutrient environments, as indicated by comparatively lower AOA to AOB ratios at higher soil horizons. In general, compared to AOA, the application of nitrogen fertilizer may lead to greater variations in the abundance and composition of AOB in paddy soils, particularly at shallow soil horizons.

While there is a body of evidence that supports the relative resistance of the AOA community to environmental extremes, other findings counter, or weaken, this generalization. For example, Ke et al. (2013) [36] reported that the level of $\mathrm{N}$ fertilization had a small effect on the abundance and community composition of the nitrifying community. In addition, a cold-water paddy field study from Guangdong province of China showed that the activity of AOB and AOA was not significantly affected by the application of compost. In contrast, the study on Korean paddy soils showed that both AOA and AOB activity significantly increased after the application of compost in paddy soils [30], indicating that both communities benefited equally from an increase in nutrients. The study on neutral soil ( $\mathrm{pH}$ 6.8-7.2) [11] demonstrated that the abundance of AOA and AOB were weakly related to soil $\mathrm{pH}$ levels, this finding, however, is presumably a result of the narrow $\mathrm{pH}$ range considered.

\subsection{Other Factors}

The study on Korean paddy soils showed that the abundances of bacterial and archaeal 16S rRNA genes are affected by seasonal variations [30]. Chen et al. (2010) [23] showed that the abundance and composition of AOA and AOB are affected by different soil types. The study on rice and wheat rotation from Jiangsu Province of China demonstrated that the application of wheat straw biochar increased the number of bacterial amoA genes [37]. Moreover, Ke et al. (2013) [36] demonstrated that soil compartments could be the most important factor that differentiate the nitrifying community activity and composition. In addition, Liu et al. (2015) [31] observed that temperature variations also have a modest effect on AOA and AOB community structures in paddy soils. Overall, our meta-analysis of factors affecting $\mathrm{AOA}$ and $\mathrm{AOB}$ abundance suggest that the AOA community is far more resistant to environmental extremes than the AOB community. While this may not be surprising given that archaea have a number of characteristics that allow them to be less sensitive to environmental extremes than bacteria, e.g., the ability to metabolize a wider variety of energy sources etc., our findings may have far-reaching implications for nitrogen cycle management and modeling. Further research is 
needed to understand the extent to which other important factors (e.g., temperature, $\mathrm{C} / \mathrm{N}$ ratio) are involved in niche differentiation of $\mathrm{AOA}$ and $\mathrm{AOB}$ in paddy soils.

\section{Conclusions}

Analysis of $\mathrm{AOA}$ and $\mathrm{AOB}$ community dynamics in paddy soils with varying edaphic conditions has revealed a number of interesting trends, both within and between groups. Despite this, further investigation is necessary to understand the environmental factors ( $\mathrm{C} / \mathrm{N}$ ratio, temperature) that shape the community structure of $\mathrm{AOA}$ and $\mathrm{AOB}$ in different paddy soils. This review confirmed that available nitrogen concentrations and $\mathrm{pH}$ levels play a crucial role in determining the activity of $\mathrm{AOA}$ and AOB in paddy soils. Further research on spatial and temporal variations of AOA and AOB in paddy soils and their contributions to nitrification is necessary.

Acknowledgments: The authors would like to thank National Taiwan University for partial finical support.

Author Contributions: The scope of this study was developed by Yu-Pin Lin and Hussnain Mukhtar. The first manuscript draft was written by Hussnain Mukhtar and Yu-Pin Lin, and was substantially revised by Yu-Pin Lin, Hussnain Mukhtar and Johnathen Anthony.

Conflicts of Interest: The authors declare no conflict of interest.

\section{References}

1. Arth, I.; Frenzel, P.; Conrad, R. Denitrification coupled to nitrification in the rhizosphere of rice. Soil Biol. Biochem. 1998, 30, 509-515. [CrossRef]

2. Chen, X.; Zhu, Y.; Xia, Y.; Shen, J.; He, J. Ammonia-oxidizing archaea: Important players in paddy rhizosphere soil? Environ. Microbiol. 2008, 10, 1978-1987. [CrossRef] [PubMed]

3. Hussain, Q.; Liu, Y.; Jin, Z.; Zhang, A.; Pan, G.; Li, L.; Crowley, D.; Zhang, X.; Song, X.; Cui, L. Temporal dynamics of ammonia oxidizer $(a m o A)$ and denitrifier (nirK) communities in the rhizosphere of a rice ecosystem from Tai Lake region, China. Appl. Soil Ecol. 2011, 48, 210-218. [CrossRef]

4. Leininger, S.; Urich, T.; Schloter, M.; Schwark, L.; Qi, J.; Nicol, G.W.; Prosser, J.I.; Schuster, S.C.; Schleper, C. Archaea predominate among ammonia-oxidizing prokaryotes in soils. Nature 2006, 442, 806-809. [CrossRef] [PubMed]

5. Dang, H.; Li, J.; Zhang, X.; Li, T.; Tian, F.; Jin, W. Diversity and spatial distribution of amoA-encoding archaea in the deep-sea sediments of the tropical West Pacific Continental Margin. J. Appl. Microbiol. 2009, 106, 1482-1493. [CrossRef] [PubMed]

6. Shen, X.-Y.; Zhang, L.-M.; Shen, J.-P.; Li, L.-H.; Yuan, C.-L.; He, J.-Z. Nitrogen loading levels affect abundance and composition of soil ammonia oxidizing prokaryotes in semiarid temperate grassland. J. Soils Sediments 2011, 11, 1243. [CrossRef]

7. Fujii, C.; Nakagawa, T.; Onodera, Y.; Matsutani, N.; Sasada, K.; Takahashi, R.; Tokuyama, T. Succession and community composition of ammonia-oxidizing archaea and bacteria in bulk soil of a Japanese paddy field. Soil Sci. Plant Nutr. 2010, 56, 212-219. [CrossRef]

8. Wang, S.; Wang, Y.; Feng, X.; Zhai, L.; Zhu, G. Quantitative analyses of ammonia-oxidizing Archaea and bacteria in the sediments of four nitrogen-rich wetlands in China. Appl. Microbiol. Biotechnol. 2011, 90, 779-787. [CrossRef] [PubMed]

9. Hou, J.; Cao, X.; Song, C.; Zhou, Y. Predominance of ammonia-oxidizing archaea and nirK-gene-bearing denitrifiers among ammonia-oxidizing and denitrifying populations in sediments of a large urban eutrophic lake (Lake Donghu). Can. J. Microbiol. 2013, 59, 456-464. [CrossRef] [PubMed]

10. Chen, X.; Zhang, L.-M.; Shen, J.-P.; Wei, W.-X.; He, J.-Z. Abundance and community structure of ammonia-oxidizing archaea and bacteria in an acid paddy soil. Biol. Fertil. Soils 2011, 47, 323-331. [CrossRef]

11. Wang, J.; Zhang, L.; Lu, Q.; Raza, W.; Huang, Q.; Shen, Q. Ammonia oxidizer abundance in paddy soil profile with different fertilizer regimes. Appl. Soil Ecol. 2014, 84, 38-44. [CrossRef]

12. Yang, X.-R.; Li, H.; Nie, S.-A.; Su, J.-Q.; Weng, B.-S.; Zhu, G.-B.; Yao, H.-Y.; Gilbert, J.A.; Zhu, Y.-G. Potential contribution of anammox to nitrogen loss from paddy soils in Southern China. Appl. Environ. Microbiol. 2015, 81, 938-947. [CrossRef] [PubMed] 
13. Lehtovirta-Morley, L.E.; Stoecker, K.; Vilcinskas, A.; Prosser, J.I.; Nicol, G.W. Cultivation of an obligate acidophilic ammonia oxidizer from a nitrifying acid soil. Proc. Natl. Acad. Sci. USA 2011, 108, 15892-15897. [CrossRef] [PubMed]

14. Erguder, T.H.; Boon, N.; Wittebolle, L.; Marzorati, M.; Verstraete, W. Environmental factors shaping the ecological niches of ammonia-oxidizing archaea. FEMS Microbiol. Rev. 2009, 33, 855-869. [CrossRef] [PubMed]

15. Wang, Y.; Ke, X.; Wu, L.; Lu, Y. Community composition of ammonia-oxidizing bacteria and archaea in rice field soil as affected by nitrogen fertilization. Syst. Appl. Microbiol. 2009, 32, 27-36. [CrossRef] [PubMed]

16. Wu, Y.; Lu, L.; Wang, B.; Lin, X.; Zhu, J.; Cai, Z.; Yan, X.; Jia, Z. Long-term field fertilization significantly alters community structure of ammonia-oxidizing bacteria rather than archaea in a paddy soil. Soil Sci. Soc. Am. J. 2011, 75, 1431-1439. [CrossRef]

17. He, J.; Shen, J.; Zhang, L.; Zhu, Y.; Zheng, Y.; Xu, M.; Di, H. Quantitative analyses of the abundance and composition of ammonia-oxidizing bacteria and ammonia-oxidizing archaea of a Chinese upland red soil under long-term fertilization practices. Environ. Microbiol. 2007, 9, 2364-2374. [CrossRef] [PubMed]

18. Avrahami, S.; Liesack, W.; Conrad, R. Effects of temperature and fertilizer on activity and community structure of soil ammonia oxidizers. Environ. Microbiol. 2003, 5, 691-705. [CrossRef] [PubMed]

19. Liu, Y.; Zhang, J.; Zhang, X.; Xie, S. Depth-related changes of sediment ammonia-oxidizing microorganisms in a high-altitude freshwater wetland. Appl. Microbiol. Biotechnol. 2014, 98, 5697-5707. [CrossRef] [PubMed]

20. Alam, M.S.; Ren, G.; Lu, L.; Zheng, Y.; Peng, X.; Jia, Z. Ecosystem-specific selection of microbial ammonia oxidizers in an acid soil. Biogeosci. Discuss. 2013, 10.

21. Ouyang, Y.; Norton, J.M.; Stark, J.M. Ammonium availability and temperature control contributions of ammonia oxidizing bacteria and archaea to nitrification in an agricultural soil. Soil Biol. Biochem. 2017, 113, 161-172. [CrossRef]

22. Tago, K.; Okubo, T.; Shimomura, Y.; Kikuchi, Y.; Hori, T.; Nagayama, A.; Hayatsu, M. Environmental factors shaping the community structure of ammonia-oxidizing bacteria and archaea in sugarcane field soil. Microbes Environ. 2015, 30, 21-28. [CrossRef] [PubMed]

23. Chen, X.; Zhang, L.-M.; Shen, J.-P.; Xu, Z.; He, J.-Z. Soil type determines the abundance and community structure of ammonia-oxidizing bacteria and archaea in flooded paddy soils. J. Soils Sediments 2010, 10, 1510-1516. [CrossRef]

24. Ke, X.; Lu, Y. Adaptation of ammonia-oxidizing microorganisms to environment shift of paddy field soil. FEMS Microbiol. Ecol. 2012, 80, 87-97. [CrossRef] [PubMed]

25. Li, H.; Weng, B.-S.; Huang, F.-Y.; Su, J.-Q.; Yang, X.-R. pH regulates ammonia-oxidizing bacteria and archaea in paddy soils in Southern China. Appl. Microbiol. Biotechnol. 2015, 99, 6113-6123. [CrossRef] [PubMed]

26. Shen, J.-P.; Zhang, L.-M.; Di, H.J.; He, J.-Z. A review of ammonia-oxidizing bacteria and archaea in Chinese soils. Front. Microbiol. 2012, 3, 296. [CrossRef] [PubMed]

27. Wang, J.; Wang, W.; Gu, J.-D. Community structure and abundance of ammonia-oxidizing archaea and bacteria after conversion from soybean to rice paddy in albic soils of Northeast China. Appl. Microbiol. Biotechnol. 2014, 98, 2765-2778. [CrossRef] [PubMed]

28. Huang, L.; Dong, H.; Wang, S.; Huang, Q.; Jiang, H. Diversity and abundance of ammonia-oxidizing archaea and bacteria in diverse Chinese paddy soils. Geomicrobiol. J. 2014, 31, 12-22. [CrossRef]

29. Wang, B.; Zhao, J.; Guo, Z.; Ma, J.; Xu, H.; Jia, Z. Differential contributions of ammonia oxidizers and nitrite oxidizers to nitrification in four paddy soils. ISME J. 2015, 9, 1062. [CrossRef] [PubMed]

30. Ahn, J.-H.; Song, J.; Kim, B.-Y.; Kim, M.-S.; Joa, J.-H.; Weon, H.-Y. Characterization of the bacterial and archaeal communities in rice field soils subjected to long-term fertilization practices. J. Microbiol. 2012, 50, 754-765. [CrossRef] [PubMed]

31. Liu, Y.; Zhou, H.; Wang, J.; Liu, X.; Cheng, K.; Li, L.; Zheng, J.; Zhang, X.; Zheng, J.; Pan, G. Short-term response of nitrifier communities and potential nitrification activity to elevated $\mathrm{CO}_{2}$ and temperature interaction in a Chinese paddy field. Appl. Soil Ecol. 2015, 96, 88-98. [CrossRef]

32. Baolan, H.; Shuai, L.; Lidong, S.; Ping, Z.; Xiangyang, X.; Liping, L. Effect of different ammonia concentrations on community succession of ammonia-oxidizing microorganisms in a simulated paddy soil column. PLoS ONE 2012, 7, e44122. [CrossRef] [PubMed] 
33. Bannert, A.; Kleineidam, K.; Wissing, L.; Mueller-Niggemann, C.; Vogelsang, V.; Welzl, G.; Cao, Z.; Schloter, M. Changes in diversity and functional gene abundances of microbial communities involved in nitrogen fixation, nitrification, and denitrification in a tidal wetland versus paddy soils cultivated for different time periods. Appl. Environ. Microbiol. 2011, 77, 6109-6116. [CrossRef] [PubMed]

34. Jiang, X.; Hou, X.; Zhou, X.; Xin, X.; Wright, A.; Jia, Z. pH regulates key players of nitrification in paddy soils. Soil Biol. Biochem. 2015, 81, 9-16. [CrossRef]

35. Wang, Y.; Zhu, G.; Song, L.; Wang, S.; Yin, C. Manure fertilization alters the population of ammonia-oxidizing bacteria rather than ammonia-oxidizing archaea in a paddy soil. J. Basic Microbiol. 2014, 54, 190-197. [CrossRef] [PubMed]

36. Ke, X.; Angel, R.; Lu, Y.; Conrad, R. Niche differentiation of ammonia oxidizers and nitrite oxidizers in rice paddy soil. Environ. Microbiol. 2013, 15, 2275-2292. [CrossRef] [PubMed]

37. Lin, Y.; Ding, W.; Liu, D.; He, T.; Yoo, G.; Yuan, J.; Chen, Z.; Fan, J. Wheat straw-derived biochar amendment stimulated $\mathrm{N}_{2} \mathrm{O}$ emissions from rice paddy soils by regulating the amoA genes of ammonia-oxidizing bacteria. Soil Biol. Biochem. 2017, 113, 89-98. [CrossRef]

(C) 2017 by the authors. Licensee MDPI, Basel, Switzerland. This article is an open access article distributed under the terms and conditions of the Creative Commons Attribution (CC BY) license (http://creativecommons.org/licenses/by/4.0/). 